\title{
ANALYSIS DEVELOPMENT OF COMPUTERIZATION ACCOUNTING INFORMATION SYSTEM IMPLEMENTATION USING TECHNOLOGY ACCEPTANCE MODEL (TAM)
}

\author{
Siti Rahmi \\ Faculty of Economic and Bussiness, Universitas Bung Hatta ,Indonesia \\ sitirahmi@bunghatta.ac.id
}

\begin{abstract}
This study aims to analyze the influence of infrastructure, human resources, costs, usefulness perceptions, and perceived ease of implementation of computerized accounting information systems. The population in this study were employees of the Padang Primary Tax Service Office. Based on the purposive sampling method, this study uses a sample of 47 respondents who work as employees of the accounting and finance department. For the dependent variable (y) of this study is the implementation of computerized accounting information systems. While for the independent variables are infrastructure (x1), human resources ( $x 2)$, costs ( $x 3)$, perceived usefulness ( $x 4)$, and perceived ease (x5). The method used is quantitative research methods. This study uses primary data from the questionnaire. Data were analyzed using multiple regression analysis which was processed through IBM SPSS Statistic software ver 20. The results of this study indicate that human resources, perceived usefulness and perceived convenience have a positive and significant effect on the implementation of computerized accounting information systems. But infrastructure and costs do not affect the implementation of computerized accounting information systems.
\end{abstract}

Keywords: Infrastructure, Human Resources, Costs, Perception of Use, Perception of Convenience, Implementation of Computerized Accounting Information Systems

\section{A. INTRODUCTION}

Companies that have sophisticated (computerized and integrated) information technology and are supported by modern technology supporting applications are expected to have a positive impact on the sustainability of the company's performance by producing timely, accurate, and reliable financial reports. (Ratnaningsih and Suaryana, 2014: 2)

Future events are difficult to predict so that the planning process to achieve company goals becomes heavier. Management needs tools to coordinate and plan limited resources to be able to compete in ever-changing environmental conditions. (Dharmayanti and Suardhika, 2015: 410)

The combination of individuals, hardware, software, communication networks, and data resources that collect, change, and distribute information in an organization is an information system. Information obtained from information processing can be used as material in decision making by the authorities in order to advance the company. (Rosani, 2011 in Devi and Suartana, 2014: 168).

The success of a system is closely related to the performance possessed by the system. The benchmark in determining the good and bad performance of an information system will be seen through the satisfaction of the user of the accounting information system itself and the user of the accounting information system. (Soegiharto, 2001 in Mardiana et al., 2014: 2)

The development of information technology began in early 1990, namely by implementing the New Payment Control System (NPCS) which serves to monitor and evaluate tax payments. In 1994, the Tax Information System (SIP) and SIPMOD (SIP Modification) were introduced to replace NPCS. (Saputra et al., 2014: 1)

In line with the development of information technology and to further improve performance, better ability to process information and ensure the security of information stored, the application of SIDJP (Information System of the Directorate General of Taxes) since 2004 has 
replaced SIP and SIPMOD developed in database software. as a database processing standard. (Lestari et al., 2013: 2)

Modern use of SIDJP is not only for one particular DGT unit, but for all KPPs throughout Indonesia. KPP which is a work unit of DGT has undergone a modernization of the system and organizational structure into a function-oriented agency not on the type of tax since 2002. So that there are three types of modern KPP: Large KPP, Medium KPP, and Primary KPP. (Lestari et al., 2013: 2)

The ALshbiel and Al-Awaqleh (2011) and Haleem (2016) studies examine the same thing, namely the influence of infrastructure and human resources on the implementation of computerized accounting information systems. The results of ALshbiel and Al-Awaqleh (2011: 50) and Haleem (2016: 137) studies show that infrastructure and human resources have a significant positive effect on the implementation of computerized accounting information systems. But the Soerosemito study (2014: 73) has different results than research conducted by ALshbiel and Al-Awaqleh (2011) and Haleem (2016). The results of this study indicate that there is no influence between infrastructure and human resources on the implementation of computerized accounting information systems.

\section{Technology Acceptance Model (TAM)}

Some models are built to analyze and understand the factors that influence the acceptance of the use of technology, including the Theory of Reasoned Action (TRA), Theory of planned Behavior (TPB), Technology Acceptance Model (TAM). (Muslichah, 2015: 171). The Technology Acceptance Model was introduced by Fred D. Davis in 1986 adopted from the Theory of Reasoned Action (TRA). The aim of the Technology Acceptance Model is to give the theory of developers the success of design, evaluation of planning and implementation of information systems. The Technology Acceptance Model is said to adopt the Theory of Reasoned Action because TRA is the basis for developing a technology acceptance model to specifically adapt information systems. The two models have something in common, they both find the underlying reason for the user to accept or reject the information system.

Theory of Reasoned Action suggests that interest in behaving is closely related to individual specific behavior, while subjective attitudes and norms are antecedents of such behavior. According to Davis (1989: 320) in the concept of Technology Acceptance Model there are two main constructs that predict interest in behaving in using information technology, namely perceived usefulness and perceived ease of use. (Davis, 1989: 320).

The development models in the Technology Acceptance Model are (1) determining how to measure the relevant behavioral components of attitudes, (2) differentiating between beliefs and attitudes, and (3) determining how external stimulation, such as objective features and causal objects connected with beliefs, attitude, and behavior. (Muslichah, 2015: 171)

Overall, the Technology Acceptance Model consists of five concepts, namely (1) perceived usefulness, (2) perceived ease of use, (3) attitudes towards use, (4) intention to use, and (5) actual use. (Davis, 1989: 320)

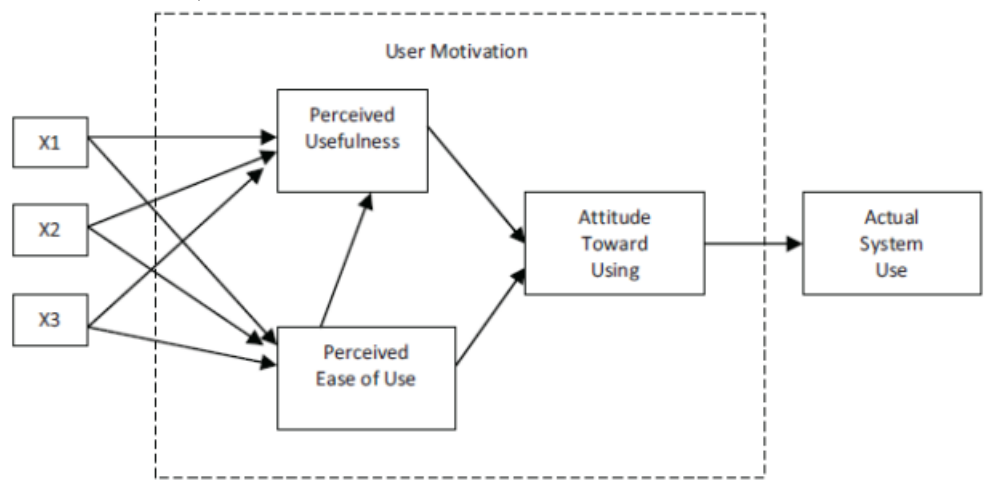

Figure 1 Original Model proposed by Fred Davis in 1989 


\section{Accounting Information System}

According to West Churchman in Krismiaji (2015: 1) the system is a series of components that are coordinated to achieve a series of goals. The system has three characteristics, namely (1) the component is something that can be seen, heard or felt, (2) the process is an activity to coordinate the components involved in a system, and (3) the goal is the ultimate goal to be achieved from the coordination of these components .

Krismiaji (2015: 14) defines information as data that has been organized, and has uses and benefits. The characteristics that must be present in the information to be useful are as follows: (1) relevant, (2) trustworthy, (3) complete, (4) timely, (5) easy to understand, (6) verifiable.

Accounting Principles Board (APB) is a committee for the preparation of accounting principles established by the American Institute of Certified Public Accounts (AICPA). The committee defines accounting as the art of recording, classifying and summarizing financial transactions and events in an efficient manner and in the form of units of money and interpretation of the results of the process.

Directorate General of Tax Information System

Currently the modern taxation information system used is SIDJP (Directorate General of Tax Information System). SIDJP is a tax administration system application that replaces SIP (Tax Information System) and SIPMOD (Modification Tax Information System). (Saputra et al., 2014: 2)

The definition of SIDJP according to Directorate General of Tax Regulation Number PER-160 / PJ / 2006 dated November 6, 2006 is "information systems in tax administration in the Directorate General of Tax's modern office environment by using hardware and software associated with a network at the Head Office" . Whereas according to SE-19 / PJ / 2007 dated April 13, 2007 the application of SIDJP is "the Directorate General of Tax Information System application that combines all taxation applications available at DGT, namely SIP, SAPT, SISMIOP, SIG, and SIDJP in the current version". (Saputra, 2014: 4)

The Information System of the Directorate General of Taxation provides supporting facilities for the creation of accurate taxpayer data with the active participation of each section in monitoring taxpayer data. The system produces reports that can be accessed by KPP, Regional Offices and DGT Headquarters.

Framework

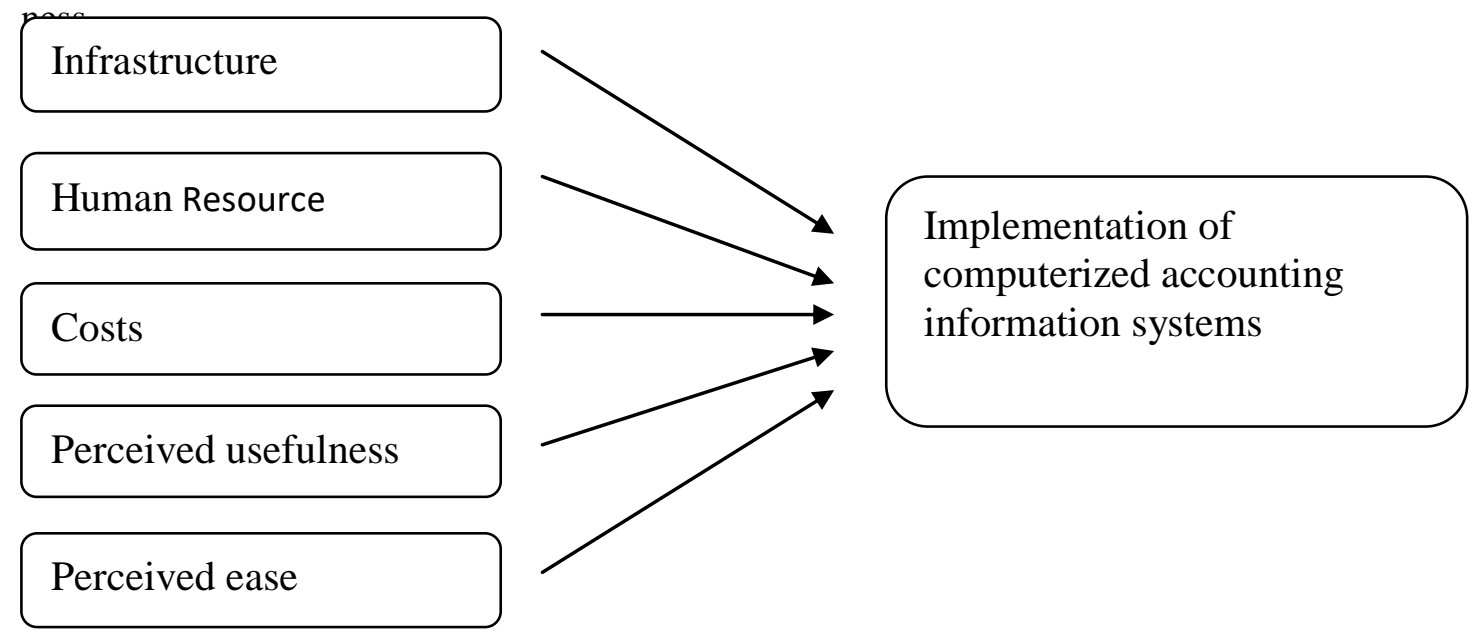

B. RESEARCH METHOD

The type of research used in this study is quantitative research. Quantitative methods are methods by which research data is in the form of numbers as a result of observation or measurement (Widoyoko, 2012: 21). This method is used to examine the effect of 
infrastructure, human resources, costs, perceived usefulness and perceived ease of implementation of computerized accounting information systems at the Pratama Tax Office in Padang.

The sample in this study were employees of the Padang Primary Tax Service Office who used or played a role in the implementation of computerized accounting information systems, employees who worked in accounting and finance, and employees who were allowed to become respondents. The sample collection technique used was purposive sampling method.

Data analysis technique

Data processing techniques in this study are directed to test hypotheses and answer all existing problem formulations. Data analysis techniques used in this study are as follows:

1. Test Reliability

According to Ghozali (2011: 47), a questionnaire is said to be reliable if the answer to the question given to someone is consistent or stable over time. To find out whether or not a variable is reliable, Cronbach Alpha statistical tests are carried out. A construct or variable is said to be reliable if it gives the Cronbach Alpha value $>0.70$ so the statement used is reliable. If Cronbach Alpha is $<0.70$, the statement used is not reliable.

Validity test

Validity tests are used to measure the validity or validity of a questionnaire. Ghozali (2011: 52) explains that a questionnaire is said to be valid if the question in the questionnaire is able to express something measured by the questionnaire.

\section{RESULT AND DISCUSSION}

Reliability Test Results

To measure reliability, the Cronbach's Alpha test was used. A variable is said to be reliable if it gives the Cronbach's Alpha value>0.60.

Table 1 Reliability and Reliability Test Results

\begin{tabular}{|l|l|l|l|}
\hline Variables & Cronbach's Alpha & Corrected item & Keterangan \\
\hline Infrastructure & 0,761 & 0,444 & $\begin{array}{l}\text { Reliabel and } \\
\text { valid }\end{array}$ \\
\hline Human Resource & 0,678 & 0,528 & $\begin{array}{l}\text { Reliabel and } \\
\text { valid }\end{array}$ \\
\hline Costs & 0,689 & 0,666 & $\begin{array}{l}\text { Reliabel and } \\
\text { valid }\end{array}$ \\
\hline Perceived usefulness & 0,623 & 0,816 & $\begin{array}{l}\text { Reliabel and } \\
\text { valid }\end{array}$ \\
\hline Perceived ease & 0,702 & 0,477 & $\begin{array}{l}\text { Reliabel } \\
\text { andvalid }\end{array}$ \\
\hline $\begin{array}{l}\text { Implementation of computerized } \\
\text { accounting information systems }\end{array}$ & & 0,528 & $\begin{array}{l}\text { Reliabel and } \\
\text { valid }\end{array}$ \\
\hline
\end{tabular}

Source: Primary data processed, SPSS 20

The table above shows Cronbach's Alpha value for infrastructure variables of 0.761, human resources of 0.678 , costs of 0.689 , usefulness perceptions of 0.623 , ease of perception of 0.702 and implementation of computerized SIA of 0.85. Thus, it can be concluded that the statement in this questionnaire is reliable because the value of Cronbach's Alpha is greater than 0.60. The table above shows the variables of infrastructure, Human Resources, Costs, Perceptions of Use, Perception of Ease and Implementation of SIA Computerization has valid criteria for all question items with a calculated $r$ value $(0.444,0.528,0.666,0.816,0.477,0.528)$ greater than $r$ table (0.3338) and has a positive value so the questions or indicators used are declared valid.

Normality Test Results 
In this study, the normality test was carried out using the Kolmogorov Smirnov test. The results of the Kolmogorov Smirnov test can be seen in the table below:

Table 2 Normality Test Results Using Kolmogorov Smirnov

\section{One-Sample Kolmogorov-Smirnov Test}

$\mathrm{N}$

Normal Param
Most Extreme
Differences

Kolmogorov-Smirnov Z Asymp. Sig. (2-tailed)
TI TSDM

47

$12.98 \quad 20.74$

Mean

Std.

Deviation

Absolute

Positive

Negative

a. Test distribution is Normal.

\section{TB}

47

TPKEB TPKEM TISIAK

$1.310 \quad 2.221$

11.26

1.799

23.85

47

21.28

$\begin{array}{rrr}.198 & .156 & .192 \\ .198 & .135 & .119 \\ -.165 & -.156 & -.192 \\ 1.357 & 1.069 & 1.319 \\ .050 & .203 & .062\end{array}$

1.978

2.243

$-.119$

.847

.470

that data is normally distributed. This can be seen from the value of Asymp. Sig. (2-tailed) in the amount of $0.050,0.203,0,062,0,218,0,068,0,470$ which is greater than 0.05 . So that this research model meets the test of the classical assumption of normality.

Multicollinearity Test Results

The following are the results of multicollinearity tests using tolerance values and VIF, as follows:

Table 3 Multicollinearity Test Results

\begin{tabular}{|c|c|c|c|}
\hline \multirow{2}{*}{ Model } & \multicolumn{2}{|c|}{ Collinearity Statistics } & \multirow{2}{*}{ Keterangan } \\
\hline & Tolerance & VIF & \\
\hline \multicolumn{4}{|c|}{ (Constant) } \\
\hline I & 0,803 & 1,245 & There is no multicollinearity \\
\hline SDM & 0,731 & 1,368 & There is no multicollinearity \\
\hline$B$ & 0,914 & 1,094 & There is no multicollinearity \\
\hline PKEB & 0,811 & 1,233 & There is no multicollinearity \\
\hline PKEM & 0,728 & 1,374 & There is no multicollinearity \\
\hline
\end{tabular}

Source: Primary data processed, SPSS 20

Based on the table above, the tolerance value is close to 1 or $>0.10$ and the VIF value is around 1 or $<10$ for each variable. Tolerance value for infrastructure is 0.83 , human resources are 0.731 , costs are 0.914 , usefulness perceptions are 0.811 , and convenience perceptions are 0.728 . Whereas for VIF value for infrastructure is 1,245 , human resources are 1,368 , costs are 1,094, usefulness perceptions are 1,233, and perceived convenience is 1,374 . Thus it can be concluded that the regression model used does not have a multicollinearity problem and can be used in this study.

Heteroscedasticity Test Results

The following are the results of the heteroscedasticity test using the values of the glejser method, as follows: 
Table 4 Heteroscedasticity Test Results

\begin{tabular}{lcl}
\hline Variable & Sig & \multicolumn{1}{c}{ Information } \\
I & 0,623 & There is no heteroscedasticity \\
SDM & 0,570 & There is no heteroscedasticity \\
B & 0,153 & There is no heteroscedasticity \\
PKEB & 0,611 & There is no heteroscedasticity \\
PKEM & 0,667 & There is no heteroscedasticity \\
\hline
\end{tabular}

Based on the table above, the probability values of infrastructure are 0.623 , human resources are 0.570 , costs are 0.153 , benefit perceptions are 0.611 , and ease of perception is 0.667 . Thus it can be concluded that there is no heteroscedasticity in all independent variables because the probability value is more than 0.05 .

Multiple Linear Regression Test Results

To find out the multiple linear regression equation used in this study, it can be seen in the table below:

Table 5 Multiple Linear Regression Test Results

\begin{tabular}{|c|c|c|c|c|c|c|}
\hline & & & Coefficients & & & \\
\hline & & $\begin{array}{l}\text { Unstand } \\
\text { Coeffic }\end{array}$ & $\begin{array}{l}\text { rdized } \\
\text { ents }\end{array}$ & $\begin{array}{l}\text { Standardized } \\
\text { Coefficients }\end{array}$ & & \\
\hline Model & & $B$ & Std. Error & Beta & $\mathrm{t}$ & Sig. \\
\hline 1 & (Constant) & 7.193 & 4.445 & & 1.618 & .113 \\
\hline & $\mathrm{TI}$ & -.261 & .243 & -.153 & -1.076 & .288 \\
\hline & TSDM & .363 & .150 & .359 & 2.418 & .002 \\
\hline & TB & .129 & .166 & .103 & .777 & .442 \\
\hline & TPKEB & .351 & .148 & .335 & 2.375 & .022 \\
\hline & TPKEM & .104 & .169 & .092 & .618 & .540 \\
\hline
\end{tabular}

a. Dependent Variable: TISIAK

Source: Primary data processed, SPSS 20

From the table above it is known that the equation in multiple linear regression in this study is

$$
\text { ISIAK }=7,193-0,261 X_{1}+0,363 X_{2}+0,129 X_{3}-0,351 X_{4}+0,104 X_{5}+e
$$

The interpretations of each variable coefficient are as follows:

1. The constant value in this study is 7.193 which means that if the five variables are 0 , then the value of the implementation of the computerized accounting information system (Y) is constant at 7.193 .

2. The infrastructure variable coefficient (X1) is -0.261 which means that if the infrastructure value rises by 1 unit then the value of the implementation of computerized accounting information system (Y) will decrease by 0.261 assuming other variables remain

3. The variable human resource coefficient (X2) is 0.363 which means that if the value of human resources rises by 1 unit then the value of the implementation of computerized accounting information system $(\mathrm{Y})$ will increase by 0.363 assuming other variables remain.

4. Cost variable coefficient is 0.129 which means that if the cost value (X3) rises by 1 unit then the value of the implementation of computerized accounting information system (Y) will increase by 0.129 assuming other variables remain. 
5. The variable usefulness perception coefficient $(\mathrm{X} 4)$ is 0.351 which means that if the value of the usefulness perception rises by 1 unit then the value of the implementation of the computerized accounting information system (Y) will decrease by 0.351 assuming other variables remain.

6. The ease of perception variable coefficient (X5) is 0.104 which means that if the perceived ease of value rises by 1 unit then the value of the implementation of computerized accounting information system (Y) will increase by 0.104 assuming other variables remain.

Model Accuracy Test

F Test Results

The $\mathrm{F}$ test results can be seen in the table. The $\mathrm{F}$ test is used to see the suitability of the regression model that has been made, the rejection area is p-value (Sig.) $<\alpha$

Table 6 F Test Results

\begin{tabular}{|c|c|c|c|c|c|c|}
\hline \multicolumn{7}{|c|}{ ANOVA $^{b}$} \\
\hline \multicolumn{2}{|c|}{ Model } & $\begin{array}{l}\text { Sum of } \\
\text { Squares }\end{array}$ & $\mathrm{df}$ & Mean Square & \multirow{2}{*}{$\begin{array}{l}F \\
4.187\end{array}$} & \multirow{2}{*}{$\begin{array}{l}\text { Sig. } \\
.004^{\circ}\end{array}$} \\
\hline \multirow[t]{3}{*}{1} & Regression & 78.220 & 5 & 15.644 & & \\
\hline & Residual & 153.184 & 41 & 3.736 & & \\
\hline & Total & 231.404 & 46 & & & \\
\hline \multicolumn{7}{|c|}{ a. Predictors: (Constant), TPKEM, TI, TB, TPKEB, TSDM } \\
\hline \multicolumn{5}{|c|}{ b. Dependent Variable: TISIAK } & & \\
\hline
\end{tabular}

Source: Primary data processed, SPSS 20

In the above table it is known that the $\mathrm{F}$ count value is 4.187 which means that it is greater than the $\mathrm{F}$ table value of 2.55 with a significance level of 0.004 which means it is smaller than 0.05 , simultaneously has a significant effect and it can be concluded that the chosen regression model is appropriate for this research.

\section{Determination Coefficient Test Results (R2)}

The coefficient of determination test (R2) is used to determine how much the ability of the dependent variable can be explained by independent variables. In this study using independent variables namely infrastructure, human resources, costs, usefulness perceptions, and perceived ease. While the dependent variable is the implementation of computerized SIA. The results of the determination coefficient test ( $\mathrm{R}$ Square) are presented in the following table:

Table 7 Determination Coefficient Test Results (R2)

\begin{tabular}{lcccc}
\hline \multicolumn{4}{c}{ Model Summary } \\
Model & $\mathrm{R}$ & $\mathrm{R}$ Square & $\begin{array}{c}\text { Adjusted R } \\
\text { Square }\end{array}$ & $\begin{array}{c}\text { Std. Error of } \\
\text { the Estimate }\end{array}$ \\
1 & $.581^{\mathrm{a}}$ & .338 & .257 & 1.933 \\
a. Predictors: (Constant), TPKEM, TI, TB, TPKEB, TSDM
\end{tabular}

In the table above shows that the $\mathrm{R}$ square value is 0.338 . This explains that $33.8 \%$ of computerized SIA implementation variables can be explained by infrastructure variables, human resources, costs, usefulness perceptions, and perceived ease. While the remaining $66.2 \%$ is explained by other variables outside the research model. 
Test Results t

The $t$ test is used to determine the influence of each independent variable individually on the dependent variable. The table presents the results of the $t$ test as a whole in this study, namely:

Tabel 8 Test Results t

\begin{tabular}{|c|c|c|c|}
\hline Model & $t$ count & $\mathrm{t}$ tabel & Sig Information \\
\hline (Constant) & 1,618 & 2,045 & 0,000 \\
\hline 1 & $-1,076$ & 2,045 & 0,288 No effect \\
\hline SDM & 2,418 & 2,045 & 0,002 Significant Positive Effect \\
\hline B & 0,777 & 2,045 & 0,442 No Effect \\
\hline PKEB & 2,375 & 2,045 & 0,022 Significant Positive Effect \\
\hline PKEM & 2,618 & 2,045 & 0,040 Significant Positive Effect \\
\hline
\end{tabular}

Source: Primary data processed, SPSS 20

\section{D.CONCLUSION AND IMPLICATION}

This study examines infrastructure, human resources, costs, perceived usefulness and perceived ease of implementation of computerized accounting information systems at the Pratama Tax Office in Padang. The analysis was carried out using the multiple regression analysis method with the Statistical Package for Social Science (SPSS) program Ver. 20.

Based on the results of the research that has been obtained, it can be concluded as a few points below:

1. Infrastructure does not affect the implementation of computerized accounting information systems. The results of this study can be seen in the results of the t test which shows that the value of $t$ count $(-1,076)$ is smaller than $t$ table $(2,045)$ with a probability value of 2,888 which means greater than 0.05 .

2. Human resources have a significant positive effect on the implementation of computerized accounting information systems. The results of this study can be seen in the results of the test which shows the value of $t$ arithmetic (2.418) greater than $t$ table (2.045) with a probability value of 0.002 which means it is smaller than 0.05 .

3. Costs do not affect the implementation of computerized accounting information systems. The results of this study can be seen in the results of the $t$ test which shows that the value of $t$ count $(0.777)$ is smaller than $t$ table (2.045) with a probability value of 0.442 which means greater than 0.05

4. Perception of usefulness affects the implementation of computerized accounting information systems. The results of this study can be seen in the results of the $t$ test which shows the value of $\mathrm{t}$ count (2.377) smaller than $\mathrm{t}$ table (2.045) with a probability value of 0.022 which means it is smaller than 0.05 .

5. Perception of ease has a significant positive effect on the implementation of computerized accounting information systems. The results of this study can be seen in the results of the test which shows the value of $t$ arithmetic (2.618) greater than $t$ table (2.045) with a probability value of 0.040 , which means smaller than 0.05 .

There are several limitations in this study. The limitations in this study are:

1. The questionnaire distributed in this study was 60 questionnaires to the accounting and finance staff at the Pratama Padang Tax Office one and two. However, the questionnaire returned only 47 questionnaires. The number of samples used in the study can affect the results of the study.

2. Data collection techniques in this study are using questionnaires. The limitations of the study using a questionnaire that is sometimes the answers given by respondents do not show the real situation, so that the effect on the results of hypothesis testing. 


\section{E. REFERENCE}

ALshbiel, S. O., and Al-Awaqleh Q. A. (2011). Factors Affects the applicability of the computerized accounting system. International Research Journal of Finance and Economics. ISSN 1450-2887 Issue 64.

Armanda, R., and Hermanto, S. B. (2015). Analysis of the factors of acceptance and use of technology in accounting information systems with the TAM approach. Journal of Accounting Science \& Research Vol. 4 No. 3.

Awosejo, O. J., Kekwaletswe, R. M., Pretorius, P., and Zuva, T. (2013). The effect of accounting information systems in accounting. International Journal of Advanced Computer Research. ISSN (print): 2249-7277 ISSN (online): 2277-7970) Volume-3 Number-3 Issue-12 September 2013.

Davis, F. D. (1989). Perceived usefulness, perceived ease of use, and user acceptance of information technology. Management Information Systems Quatyery Vol. 13 September 3, 1989, pp. 319-340.

Devi, N. L. N. S., and Suartana, I. W. (2014). Analysis of technology acceptance model (TAM) on the use of information systems at Nusa Dua Beach Hotel \& SPA. Accounting EJournal of Udayana University 6.1: 167-184. ISSN: 2302-8556.

Dharmayanti, N. M., and Suardikha M. S. (2015). Analysis of factors that influence management performance due to the use of accounting information systems. Accounting E-Journal of Udayana University 12.2: 409-421. ISSN: 2302-8556.

Estiningrum, S. D. (2013). Accounting. Tulungagung: STAIN Tulungagung Press.

Ghozali, I. (2011). Multivariate Analysis Application with IBM SPSS 20 Program.Semarang: BP UNDIP. ISBN 979.704,015.1. (2012). Multivariate Analysis Application with IBM SPSS 20 Program. Semarang: BP UNDIP. ISBN 979.704,015.1.

Githinji, C. K., Kiminda, R. W., Ofunya. F. A. (2014). Adoption of computerized accounting systems by Coffee Societies in Nyeri County, Kenya. European Journal of Business and Social Sciences, Vol. 3, No.3, p.p 88-103, June 2014. ISSN: 2235 -767X

Haleem, A. (2016). The factor affecting is computerized accounting system with the reference to government department in the Ampara District. EPRA

International Journal of Economic and Business Review Vol. 4, Issue. 7, July 2016. e-ISSN: 2347 - 9671, p-ISSN: 2349 - 0187. http://www.kppbumn.depkeu.go.id

Indriantoro, N., and Supomo B. (2014). Business Research Methods (For Accounting and Management). Yogyakarta: BPFE Yogyakarta.

Jogiyanto. (2009). Information Technology System. Yogyakarta: Andi Offset.

Krismiaji. (2015). Accounting information system. Yogyakarta: STIM YKPN.

Kurniawan. (2012). IT experts become witnesses to the case of the Directorate General of Tax Information System. August 29, 2012. http://news.okezone.com. 
Lestari, M., Kertahadi., And Suyadi, I. (2013). Effectiveness of the Directorate General of Tax Information System (SIDJP). Journal of Business Administration (JAB) Vol. 6 No. December 2, 2013.

Mardiana, I.G.E.P., Sinarwati, N.K., and Atmadja, A.T. (2014). Analysis of factors that influence the performance of the accounting information system (SIA) in Village Credit Institutions (LPD) in Susut District. S1 E-Journal Ak University of Education Ganesha Accounting Department S1, Volume: 2 No. 1 of 2014.

Mulyadi. (2010). Cost accounting. Yogyakarta: STIE YKPN.

Muslichah, I. (2015). An antecedent analysis of the attitudes and intentions of using a Blackberry with the basis of a technology acceptance model. Business Strategy Journal. Volume 19 No 2, July 2015. ISSN 0853-7666.

Ratnaningsih, K. I., and Suaryana, I. G. N. A. (2014). The influence of information technology sophistication, management participation, and accounting manager knowledge on the effectiveness of accounting information systems. Accounting E-Journal of Udayana University 6.1: 1-16. ISSN: 2302-8556.

Rivai, V., and Sagala, E. J. (2011). Human Resource Management for the Company. Jakarta: Rajawali Press.

Romney, M. B., and Steinbart, P. J. (2005). Accounting Information System (Ed. 9th). Jakarta: Salemba Empat.

Romney, M. B., and Steinbart, P. J. (2014). Accounting Information System (Ed. 13th). Jakarta: Salemba Empat.

Saputra, R., Astuti, E. S., and Rahardjo, K. (2014). Analysis of the use of directorate general tax information system applications (SIDJP) and employee performance. Journal of Taxation Vol. 3 No. November 1, 2014.

Soerosemito, V.N. (2014). Effect of Infrastructure, Human Resources, Managerial Performance, E-Decision, and Software on the Implementation of Computerized Accounting Information Systems. (Thesis. Sebelas Maret University Surakarta).

Sugiyono. (2014). Quantitative, qualitative, and R \& D research methods. Bandung:

Sulistyani, A. T., and Rosidah. (2009). Human Resource Management. Yogyakarta: Graha Ilmu.

Sulistyowati, L. (2013). Analysis of Factors Affecting the Implementation of Computerized Accounting Information Systems. (Thesis. Sebelas Maret University Surakarta.

Sutrisno, E. (2015). Human Resource Management. Jakarta: Kencana.

Winidyaningrum, C., and Rahmawati. (2010). The influence of human resources and the use of information technology on the reliability and timeliness of local government financial reporting with intervening variables on internal accounting controls. National Accounting Symposium XIII. October 13-14, 2010.

Wiyono, G. (2011). Designing Business Research with the SPSS 17.0 and Smart PLS 2.0 Analysis Tools. Yogyakarta: STIM YKPN. 